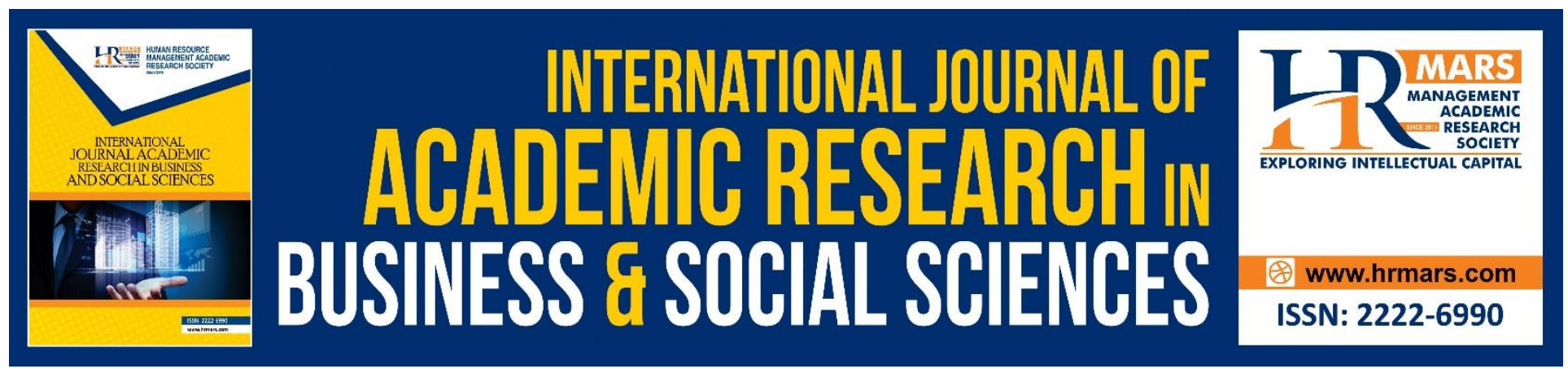

\title{
Factors Affecting Young Shoppers' Online Shopping Preference in Kelantan, Malaysia
}

Nazaria Binti Md. Aris, Ruziah A. Latif, Nurnais Safiy Binti Zainal, Khalisah Khairina Binti Razman, Razman Bin Anuar

To Link this Article: http://dx.doi.org/10.6007/IJARBSS/v11-i14/9618

DOI:10.6007/IJARBSS/v11-i14/9618

Received: 02 January 2021, Revised: 10 February 2021, Accepted: 28 February 2021

Published Online: 23 March 2021

In-Text Citation: (Aris et al., 2021)

To Cite this Article: Aris, N. B. M., Latif, R. A., Zainal, N. S. B., Razman, K. K. B., \& Anuar, R. Bin. (2021). Factors Affecting Young Shoppers' Online Shopping Preference in Kelantan, Malaysia. International Journal of Academic Research in Business and Social Sciences, 11(14), 417-430.

Copyright: (C) 2021 The Author(s)

Published by Human Resource Management Academic Research Society (www.hrmars.com)

This article is published under the Creative Commons Attribution (CC BY 4.0) license. Anyone may reproduce, distribute, translate and create derivative works of this article (for both commercial and non-commercial purposes), subject to full attribution to the original publication and authors. The full terms of this license may be seen

at: $\underline{\text { http://creativecommons.org/licences/by/4.0/legalcode }}$

Special Issue: Contemporary Business and Humanities Landscape Towards Sustainability, 2021, Pg. 417 - 430

http://hrmars.com/index.php/pages/detail/IJARBSS

JOURNAL HOMEPAGE

Full Terms \& Conditions of access and use can be found at

http://hrmars.com/index.php/pages/detail/publication-ethics 


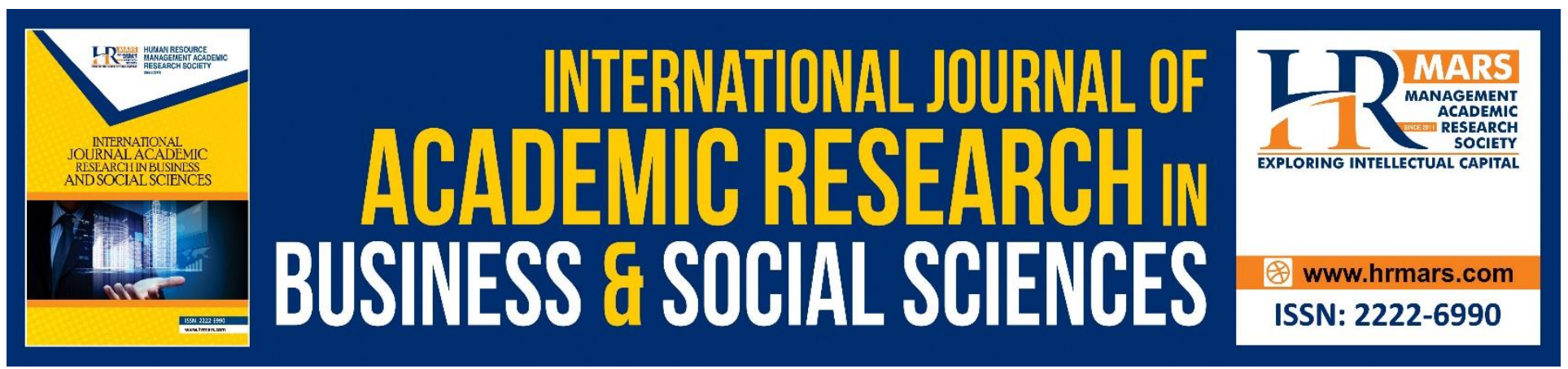

\title{
Factors Affecting Young Shoppers' Online Shopping Preference in Kelantan, Malaysia
}

\author{
Nazaria Binti Md. Aris ${ }^{1}$, Ruziah A. Latif ${ }^{2}$, Nurnais Safiy Binti Zainal ${ }^{3}$, \\ Khalisah Khairina Binti Razman ${ }^{4}$, Razman Bin Anuar ${ }^{5}$ \\ 1, 4,5 Faculty of Economics and Business. Universiti Malaysia Sarawak, Kota Samarahan, Sarawak, \\ 2, 3 Faculty of Business Management. Universiti Teknologi MARA, Segamat, Johor \\ Email: manazaria@unimas.my
}

\begin{abstract}
The growth of online shopping is impressive. The presence of social media platforms accelerates the way companies connect directly with consumers. In other words, consumers use internet as shopping channel instead of physically walk into the traditional brick-and-mortar retail stores. Nowadays, majority of the young people are associated with technologies and digital media. Online shopping has become a significant part of their lifestyle. The objective of this study concerns to understand the demography and perceptions towards online shopping orientation of young Malaysian in Kelantan. Therefore, a sample of 101 young shoppers in Kota Bharu, Kelantan were asked for input and descriptive analysis was done to examine factors shaping their online shopping preference. Based on the result, the study highlighted three significant findings. Perceived ease of use, perceived usefulness and past online shopping experience are the key factors which influence online shopping orientation for young shoppers. Consequently, the finding is important for business developers to form their e-marketing strategies in creating a highly convenient e-store platform to fit the changing needs of young shoppers' lifestyles towards online shopping experience especially in Kelantan.
\end{abstract}

Keywords: Online Shopping, Young Shoppers, Shopping Perception, Shopping Preference.

\section{Introduction}

Electronic commerce (e-commerce) has helped businesses and individuals to buy and sell products by providing cheaper and wider distribution channels using internet. With the advent of online shopping in Malaysia in this era of globalization, physical access to crowded stores are replaced with just a few clicks away i.e. online shopping. Online shopping refers to electronic businesses that allows consumers to bargain items or services from the merchant through web. E-commerce also known as internet traded, refers to the purchase and sale of merchandise or services using the internet and can also be described as any type of business transaction facilitated through the internet. E- commerce can give huge economic advantages for sellers and purchasers because of data and technology accessibility, new online services, access to different markets, lower transaction 
costs, sped up and precision, and shorter conveyance times (Janson \& Cecez-Kecmanovic, 2005). In the real online-shopping circumstances, online reviews of the items have numerous positive reviews and a few negative reviews (Chu, 2017). According to Sheikh et al., (2019) the social commerce constructs (SCC) employed by online sellers facilitate online communication and consumer social interaction. Customers not only purchase the product online but also compare the costs, product characteristics and after-sales service facilities they obtain from a specific store (Shergill \& Chen, 2005). This includes recommendation systems, reviews, ratings, and virtual group and forum development. Besides the great potential of the e-commerce market, the online shopping platform offers companies a special and unique opportunity to achieve existing and potential customers more efficiently. For online stores like Amazon and eBay, customer reviews on their websites add value in creating prospective consumers. Hence, for producers, buyers are their key motivations to produce and sell their products and services.

Gabor's early research (1979) suggested that there are two variables, among mainstream consumers, which are imperative in shaping consumer behaviours viz. price and patronage preferences. It is important to recognize how consumers perceive their shopping behaviours and according to Kacen et al. (2013), the marketer affects most consumer behaviour by gender, age, social status and advertising. Due to the advent of online shopping, there are other determinants which lead to shopping perception and preference of the consumers. Therefore, the intent of this study is to explore the key factors affecting online shopping preference among buyers whom are young shoppers. Therefore, this study has been conducted based on the objectives identified as follows:

i. To examine the demographic determinants for online shopping buyers among young shoppers in Kelantan.

ii. To analyse descriptively the key elements influencing the online shopping preference among the young shoppers in Kelantan.

This study may prompt significant approach suggestion for government or administrative bodies in actualization better and viable e-commerce practices so as to improve business activities. Apart from that, it helps the Malaysian marketers to produce their own marketing strategies or formula to attract the young shoppers to buy online. Moreover, the importance of this study is to create awareness on the factors that shaped the online shopping preference for young shoppers especially for traditional retail shops who wish to join e- commerce.

\section{Statement of the Problem}

In this study, there are two significant gaps that encouraged this study to be carried out in Kelantan. First, since the late 2000s, Kelantan has undergone major economic and social changes whose impact is expressed on all levels, including trends of online shopping behaviour. After opening the door to foreign investment in conjunction with the Eastern Coast Economic Region (ECER), which attracted investment worth RM72,26 billion as of 2014, a number of global retailers are preparing to enter this market or raise their investments. Measures have been implemented to facilitate privatization initiatives, encourage significant investment in economic life by the private sector, attract foreign capital and achieve economic growth and stability. Sadly, today, the results have been modest and participation is less than the level expected, and it is evident that public economic institutions tend to dominate. The shifts in the marketing system remain uncertain and no facts could be used to examine the situation. In order to achieve the research objectives, a theoretical 
INTERNATIONAL JOURNAL OF ACADEMIC RESEARCH IN BUSINESS AND SOCIAL SCIENCES

Vol. 11, No. 14, Special Issue: Contemporary Business and Humanities Landscape Towards Sustainability, 2021, E-ISSN: 2222-6990 @ 2020 HRMARS

framework was developed based on the existing literature in the area of consumer behaviour. There is an extensive study has been done in this context, indicating this is a mature area. Nevertheless, little study actually focuses on East Peninsular especially Kelantan. Therefore, this study used the existing research to develop a theoretical framework and validated this framework to a particular context, in this case, Kelantan. For this study, survey has been conducted in Kota Bharu.

Second, Akroush \& Al-Debei (2015) stated that, online shopping would reduce the threat of substitution and provide long-term profitability. According to News Strait Times dated 29 March 2019, reported that in 2018 percentage of household access to the internet increased by $15.6 \%$ to $85.7 \%$ compared to $70.1 \%$ in 2015 . This means that with this internet penetration rate can open great business online opportunities. Unfortunately, shops likes Bata, Aeon, Pacific, Giant and others in Kelantan are still not using online platform to sell and promote their product to more target market especially among young shoppers. Research on online shopping has been limited among young and educated customers relatively in many economic contexts, although they are the largest demographic group (Jibril et al. 2020). Therefore, drawing on these significant gaps and conflict of findings, this study aims to fill this knowledge gaps by investigating some fundamental factors influencing young shoppers' perception on online shopping preference specifically in Kelantan.

\section{Literature Review}

\section{Young shoppers in Malaysia}

Young shoppers are being targeted for this study because in prior survey indicated that more than half of the Malaysian population responded positively on online shopping in the previous 3 years and most of these online consumers comprised of the youth who have been overwhelmed with digital marketing particularly on social media platforms like Facebook, Instagram, Pinterest, WhatsApp, Snap Chat, Twitter and other media sharing networks. Thus, this youth cluster has experienced the largest impact of the increase in purchasing power in Malaysia. Among the different age groups of users, young people or young shoppers consider themselves most relaxed using technology (Mishra \& Ayatham, 2017). Companies believe that if they can win the loyalty of young people, they will continue to be their customers all their lives. Consumers would opt for social shopping rather than traditional shopping because it fulfils the unmet social needs of consumers, particularly young consumers (Wu et al., 2018). Malaysia has many young people who can readily embrace the use of technology in industry as the median age is around 25 to 26 years old for both male and female Malaysians. The influence of young people on social media has also given Malaysians a great opportunity to embrace e-commerce. Many Malaysians are literate in computers and can communicate in several languages for example, Malay, English , Chinese, Tamil and other languages which enable them to communicate easily with different people in other parts of the world.

\section{Online shopping preference}

Perceived ease of use

In this study, convenience in comparing products and prices, easier to select the right product, easy online payment method, and ability to save time from going to the physical store was surveyed to study on the young shoppers' perceived ease of use. Parker \& Wang, (2016) elaborated that the customer's online purchasing decision making activity is composed of 10 steps. Firstly, consumers 
INTERNATIONAL JOURNAL OF ACADEMIC RESEARCH IN BUSINESS AND SOCIAL SCIENCES

Vol. 11, No. 14, Special Issue: Contemporary Business and Humanities Landscape Towards Sustainability, 2021, E-ISSN: $2222-6990$ @ 2020 HRMARS

are encouraged to shop online, locate websites and use the internet. They then search for products they want to buy, review products such as viewing product information images, analyze and compare alternatives such as consumer feedback scanning, compare prices with various websites, then make a temporary buying decision, pay, obtain the products and eventually decide to accept or reject the products. It shows that motivation play importance role in decision making for buying and selling. Hence, this hypothesis is developed:

$\mathrm{H} 1$ : There is a significant relationship on young shoppers' perception about the ease of use in online shopping

\section{Perceived usefulness}

Next, this study surveyed on young shoppers' perceived usefulness of online shopping was measured cost savings, consuming lower prices through promotion and more convenient to find and select unique items through online shopping. According to Wu et al., (2018) some scholars argue that social value would help influence consumer purchasing intentions because it fulfils the social motivations of consumers, such as getting acquainted with like-minded members, interacting with others and referral group affiliation. Seo \& Moon, (2016) examined reasons for online clothing consumption with American college students using CSI. Their study found a strong link between awareness of quality, brand awareness, fashion awareness, hedonistic shopping, impulsivity and brand loyalty and online clothing shopping. It shows that motivation can be contributing factors of consumer uses online shopping. Meanwhile, Narges et al., (2011) said the shopping attitude of an person is affected by four main psychological factors, such as motivation, awareness, conviction and attitude. Based on the Theory of Reasoned Action (TRA), Cha (2011) the study suggested that subjective norms are positively associated to purchase intention of actual and virtual things by young graduates students. This indicates the higher social influence on online purchase, the higher they will complete the online purchase process. Chen and Cheng ( 2009) confirmed the statements of the TRA by contributing four modifications to DeLone and McLean model. They demonstrated the association between satisfaction and behavioural intention and perceived use on online shopping intentions. Convenience is one of online shopping's most influential advantages (Bhatnagar \& Ghose, 2004; Forsythe et al., 2006). Thus, the following hypothesis is developed:

$\mathrm{H} 2$ : There is a significant relationship on young shoppers' perception about the usefulness of online shopping

\section{Perceived past experience}

This study also measured young shoppers' past online shopping experiences in terms of their perceptions related to receiving the right product ordered, prompt delivery and feeling satisfaction with the service. Consumers will continue to shop online in the future when they gained good and beneficial experience (Shim et al., 2001). A study by Dholakia and Uusitalo (2002) indicated that The perceived hedonic and utilitarian advantages of in-house shopping, including catalogue, television and internet shopping, have a positive effect. Therefore, the following hypothesis is developed:

H3: There is a significant relationship on young shoppers' perception about their past experience and online shopping 


\section{Perceived uncertainty}

The perceived uncertainty of online shopping was measured related to undelivered of the ordered items, not receiving the product on time, the product is not in good condition and wrong product delivery. There are many risks during the online shopping process, such as product performance, finance, time, convenience. The risk of product performance is characterized as the uncertainty concerning functional aspects of the product (Shimp \& Bearden, 1982). Financial risk has been defined as uncertainty about possible financial losses related to internet transaction security threats or service interruptions (Grewal et al., 1994). Consumers may perceive a risk of time or convenience due to challenges or disruptions in navigating the website, submitting an order or awaiting for online shopping arrival (Biswas \& Biswas, 2004; Forsythe \& Shi, 2003). Early adopters typically enjoy a high degree of creativity and their initial decision to adopt is often driven by interest and epistemic value. However, after initial adoption, their decision to continue the innovation or not depends primarily on their own views and previous experience (Al-debei, Akroush, \& Ashouri, 2015). Perceived risk involves uncertainty phenomenon that caused customers' subjective measurements in the process of decision making whether the decision to purchase is wrong or not suitable (Murphy \& Enis, 1986). The theory of consumers' perceived risk by Taylor (1974) suggested that customers' perceive risk in the state of uncertainty and undesirable situation when making unsuitable decision. Along with perceived waiting time, the perceived risk was both an antecedent to the abandonment of the shopping cart. (Rajamma et al., 2009). Thus, the developed hypothesis is:

$\mathrm{H}$ 4: There is a significant relationship on young shoppers' perception about the uncertainty of online shopping.

\section{Perceived security}

Lastly, in this study, the young shoppers' perceived security of online shopping surveyed whether they are comfortable using credit cards with no unauthorized charges, feel safe about identity protection and consider online retailers trustworthy. For this reason, many internet subscribers withdrawn themselves from trading over the internet (Labuschagne, 2000). In today's competitive business strategy, electronic commerce has become a critical component, even though, the electronic infrastructure that supports online transaction. However, with this development, some new problems and challenges have arisen, including security of payment, data protection, e-contract validity and enforceability, inadequate information disclosure, product quality and enforcement of rights (Kamalul Ariffin et al., 2018). As a step to foster consumer confidence, Jordan's online shopping websites pay attention to privacy and security aspects as major drivers of reducing perceived risks from the perspective of online consumers. It is because privacy and security were widely recognized as two of the main barriers to adoption. (Al-debei et al., 2015). Therefore, the developed hypothesis is:

H5: There is a significant relationship on young shoppers' perception about security and online shopping.

\section{Research Location}

This study focus on online shopping perception and its determinants (perceived ease of use , perceived usefulness, past online shopping experience, perceived uncertainty and perceived security) among young shoppers that shaped their shopping preference in Kota Bharu, Kelantan. The study location is based in Kota Bharu, Kelantan, a northeast state in Peninsular Malaysia. This 
particular state was chosen because it is rural in geographical context and economically less developed than the major cities in western Malaysia. According to Khazanah Research Institute (KRI), Kelantan is the poorest state by nominal GDP per person and second from the bottom in terms of nominal GDP, lies between richer Indonesia and poorer Sri Lanka in terms of GDP per person. As a typical rural state, Kelantan is facing many kinds of supply constraints like the inaccessibility of skilled labour, the trouble in getting crude materials, the hesitance to embrace modern strategies of productions or technology, the scarcity of credit facilities, the insufficiency of quality control measures in the productions process and others. Consequently, with the rising rates of online shopping users in Malaysia, there are some companies or retailers reluctant to adopt e-commerce platform as new business penetration method in Kelantan. This reluctant to adopt e-commerce are related to not all houses are wired up to receive internet services through telephone lines or wireless. Nevertheless, Internet facilities are accessible at Internet cafes, colleges, and university computer labs or offices where the respondents are studying or working. For the purpose of this study, only those using the Internet have been interviewed.

\section{Methodology}

This study took place in two stages. First, an exploratory research design was adopted and qualitative data was collected. The data was used to understand the problems, gathering information about young shoppers' perception regarding online shopping and refined the questionnaire design before construct the five research hypotheses. Primary data collection technique through consumer survey method was developed. The data was gathered among all young shoppers age between 15 and 35 living in 10 districts of Kelantan, Malaysia. The questionnaire was used as the instrument for data collection. There are two sections in the questionnaire. The first section was the information on respondent's demographic profile. The second section was questions on motivational factors that influence online shopping preference. Here, the five dimensions of the independent variables were asked namely perceived ease of use, perceived usefulness, past online shopping experience, perceived uncertainty and perceived security.

In second stage, a descriptive analysis was conducted to investigate factors that influence the young shoppers' online shopping preference. This quantitative study was to analyse and understand young shoppers' shopping behaviour and check if the concepts and survey questions taken from other studies fitted with the Kelantan case. This second section was on the buyer's likelihood of buying products using online shopping. Descriptive Analysis, Factor Analysis, Reliability Test, Regression analysis, Pearson's Coefficient of Correlation, and Multiple Linear Regressions were performed using the Statistical Package for Social Sciences (SPSS) to analyze data obtained through the questionnaire for better results and findings.

\section{Data Analysis}

A total of 101 questionnaires were distributed, returned and used for data analysis. Table 1 summarized the main characteristics of the respondents and the frequencies test against all demographic variables used in this study. The survey results indicate that among the respondents, female respondents $58.4 \%$ (59) were higher than male respondents $41.6 \%$ (42). $83.2 \%$ (84) of the respondents are aged between 15 to 30 years old while $16.8 \%$ (17) is above 31 years old. Moreover, the result indicates all respondents use online shopping and majority of them do their online shopping more than once a month. 
INTERNATIONAL JOURNAL OF ACADEMIC RESEARCH IN BUSINESS AND SOCIAL SCIENCES

Vol. 11, No. 14, Special Issue: Contemporary Business and Humanities Landscape Towards Sustainability, 2021, E-ISSN: 2222-6990 @ 2020 HRMARS

Table 1: Respondents' Demographic Profile

\begin{tabular}{|c|c|c|c|}
\hline Respondent's & Profile & $\begin{array}{c}\text { Frequency } \\
(n=250)\end{array}$ & $\begin{array}{l}\text { Percent } \\
(100 \%)\end{array}$ \\
\hline \multirow[t]{4}{*}{ Gender } & Male & 42 & 41.6 \\
\hline & Female & 59 & 58.4 \\
\hline & SPM & 24 & 23.8 \\
\hline & STPM & 7 & 6.9 \\
\hline \multirow[t]{3}{*}{ Education } & Diploma & 24 & 23.8 \\
\hline & Degree & 41 & 40.6 \\
\hline & Master & 5 & 5 \\
\hline \multirow[t]{2}{*}{ Age } & $15-30$ & 84 & 83.2 \\
\hline & $>31$ & 17 & 16.8 \\
\hline \multirow[t]{2}{*}{ Income } & Below than RM5000 & 85 & 84.2 \\
\hline & More than RM5000 & 16 & 15.9 \\
\hline \multirow{2}{*}{$\begin{array}{l}\text { Frequency of Online } \\
\text { Shopping }\end{array}$} & Once a month & 41 & 40.6 \\
\hline & $\begin{array}{l}\text { More than once a } \\
\text { month }\end{array}$ & 60 & 59.4 \\
\hline \multirow[t]{2}{*}{ Online Buying } & Yes & 101 & 100 \\
\hline & No & 0 & 0 \\
\hline
\end{tabular}

Table 2 presents the descriptive statistics for all variables reported in the table below. There are five dimensions that have been shown to influence online shopping preference for young shoppers viz. perceived ease of use (EU), perceived usefulness (PU), past online shopping experience (PE), perceived uncertainty (UC) and perceived security (PS). The statistics indicate the highest mean for variables is 4.191 while the lowest mean score is 3.831 . The, highest value of standard deviation is 0.809 and the lowest value is 0.666 . The minimum and maximum value of the responses are also presented in Table 3. Briefly, all variables in the statistics are above satisfactory level and respondent agrees with the statement. 
INTERNATIONAL JOURNAL OF ACADEMIC RESEARCH IN BUSINESS AND SOCIAL SCIENCES

Vol. 11, No. 14, Special Issue: Contemporary Business and Humanities Landscape Towards Sustainability, 2021, E-ISSN: 2222-6990 @ 2020 HRMARS

Table 2: Descriptive Statistics of the Variables

\begin{tabular}{|c|c|c|c|c|}
\hline Variables & Minimum & Maximum & Mean & Std. Dev. \\
\hline OS & 1.83 & 5.00 & 4.112 & 0.699 \\
\hline EU & 2.20 & 5.00 & 4.093 & 0.666 \\
\hline PU & 1.25 & 5.00 & 4.180 & 0.716 \\
\hline PE & 2.33 & 5.00 & 4.191 & 0.585 \\
\hline UC & 1.40 & 5.00 & 3.853 & 0.809 \\
\hline PS & 1.86 & 5.00 & 3.831 & 0.708 \\
\hline
\end{tabular}

*Five-points scale:1: strongly disagree; 5: strongly agree

Reliability test was performed on the data and the results indicated Cronbach's Alpha value are all greater than 0.5 which means that all variables are reliable and with high level of internal consistency. In addition, factor analysis was performed using the KMO and Bartlett's Test. Based on the results, the measure of sampling adequacy is suitable the measure of sampling adequacy is suitable. Correlation coefficient was used in this study is to evaluate the relation between dependent and independent variables. Table 3 indicates there is a positive significant relationship between OS and EU,PU,PE,UC and PS at 0.01 level. A regression analysis were run to show the $t$-value and $p$ value of each variable that included in this study.

Table 3: Correlation Analysis

\begin{tabular}{|c|c|c|c|c|c|c|}
\hline & OS & EU & PU & PE & UC & PS \\
\hline OS & 1 & $0.861^{* *}$ & $0.845^{* *}$ & $0.584^{* *}$ & $0.687^{* *}$ & $0.600^{* *}$ \\
\hline EU & $0.861^{* *}$ & 1 & $0.787^{* *}$ & $0.556^{* *}$ & $0.746^{* *}$ & $0.683^{* *}$ \\
\hline PU & $0.845^{* *}$ & $0.787^{* *}$ & 1 & $0.534^{* *}$ & $0.644^{* *}$ & $0.575^{* *}$ \\
\hline PE & $0.584^{* *}$ & $0.556^{* *}$ & $0.534^{* *}$ & 1 & $0.436^{* *}$ & $0.360^{* *}$ \\
\hline UC & $0.687^{* *}$ & $0.746^{* *}$ & $0.644^{* *}$ & $0.436^{* *}$ & 1 & $0.655^{* *}$ \\
\hline PS & $0.600^{* *}$ & $0.683^{* *}$ & $0.575^{* *}$ & $0.360^{* *}$ & $0.655^{* *}$ & 1 \\
\hline
\end{tabular}

** The correlation at level 0.01 is significant (2-tailed). 
INTERNATIONAL JOURNAL OF ACADEMIC RESEARCH IN BUSINESS AND SOCIAL SCIENCES

Vol. 11, No. 14, Special Issue: Contemporary Business and Humanities Landscape Towards Sustainability, 2021, E-ISSN: 2222-6990 @ 2020 HRMARS

Table 4: Regression Analysis

\begin{tabular}{|c|c|c|c|c|c|c|}
\hline \multirow[b]{2}{*}{ Model } & \multicolumn{2}{|c|}{$\begin{array}{l}\text { Unstandardized } \\
\text { Coefficients }\end{array}$} & \multicolumn{2}{|c|}{$\begin{array}{l}\text { Standardized } \\
\text { Coefficients }\end{array}$} & \multicolumn{2}{|c|}{$\begin{array}{l}\text { Collinearity } \\
\text { Statistics }\end{array}$} \\
\hline & B & Std. Error & Beta & & VIF & \\
\hline (Constant) & 0.008 & 0.211 & & 0.038 & & 0.97 \\
\hline EU & 0.481 & 0.092 & 0.458 & 5.231 & 4.083 & $0.000 * *$ \\
\hline PU & 0.401 & 0.071 & 0.411 & 5.686 & 2.787 & $0.000 * *$ \\
\hline$P E$ & 0.083 & 0.047 & 0.095 & 1.777 & 1.504 & $0.079 * * *$ \\
\hline UC & 0.042 & 0.059 & 0.049 & 0.710 & 2.513 & 0.480 \\
\hline PS & -0.015 & 0.062 & -0.015 & -0.248 & 2.067 & 0.805 \\
\hline F Value & \multicolumn{6}{|c|}{87.428} \\
\hline Sig. & \multicolumn{6}{|c|}{0.000} \\
\hline $\begin{array}{l}\text { Adjusted } \\
\text { R square }\end{array}$ & \multicolumn{6}{|c|}{0.812} \\
\hline R Square & \multicolumn{6}{|c|}{0.821} \\
\hline
\end{tabular}

Notes: $* * *$ and $* *$ denotes the statistically important at $10 \%$ and $1 \%$ level respectively.

The results in Table 4 showed that three factors EU, PU and PE, significantly affect the online shopping preference for young shoppers. This result indicates that young shoppers perceived that online shopping is easy because of the perceived benefits gained from positive experiences to shop online. On the other hand, UC and PS were found to be insignificant to online shopping preference. This result means young shoppers who perceived that online shopping is high risk and high uncertainty prefer the traditional way, shopping at the physical store.

\section{Conclusion and Recommendation}

From the above results, it is found there are three main factors namely perceived ease of use of online shopping, perceived usefulness of online shopping and past online shopping experience that can shape the online shopping preference among young shoppers in Kelantan. These three factors are positive associated to their online shopping preference. No significant relationships were found between perceived uncertainty and perceived security of online shopping for young shoppers in Kelantan. It is observed that most young shoppers perceived that the benefits from easy to use of online shopping is vital when doing internet shopping. Young online shoppers in Kelantan considered online shopping eased the process of comparing the goods and prices, saving time and cost in choosing the right product and making online payment convenience. The online shopping is more appealing from offline stores for young shoppers in Kelantan because the online retailers provide more competitive prices and varieties of products with exciting shopping offers that make them feel good and at ease when adopting online shopping. This finding is supported by Urvashi Tandon, (2017) where the study focused on time performance, product related and promotion. The online shopping platform is a cost saving to consumer where there is no need to go or travel to the shops and consumer can choose product from any vendor anywhere, obtain information and compare the price before purchase with the assistance of online services. Similarly, Arora \& Aggarwal (2018) found that 
comfortability has a positive influence on the perception of online shopping attitude and online shopping intention. There are few studies examined the negative aspects of satisfaction such as dissatisfaction and complaint behaviour especially in the online context (Izogo \& Jayawardhena, 2018). Clearly, this signifies that in order for the online retailers to increase their sales from young shoppers, they must increase speed and convenience by providing user-friendly and less mental effort websites. Young shoppers prefer to use the most advanced technology in doing business by computer as it is efficient and mentally stimulating as less human pressure or intervention. They can tailor things to their own needs and do a great deal more now than before with the available advanced technology. Perceived usefulness on online shopping has positive significant result in this study. This means that the online shopping is useful in helping young shoppers in Kelantan to buy online. This result is supported by Kim and Park (2013) as cited in Seo and Moon (2016), because of the popularity of social network sites such as Facebook and Instagram, social commerce is a new field of e-commerce. As social network sites are used for social interaction, this enable customers to share product or service reviews and provide knowledge from their own experience that influences the decision making of other consumers. Hence, young shoppers perceived this useful piece of information attracted them to purchase through the social media platform. In other words, they look for hedonic values such as adventure / exploration, social, idea, value, authority and status on the Internet. Thus, the perceived usefulness affects the young shoppers' preference on online shopping because online shopping is fun, make them feel good and they enjoy the exciting shopping offers. The result from this study shows past online shopping experience is significant in moulding the young shoppers' online shopping preference. Young shoppers in Kelantan perceived that satisfaction with past online purchases lead them to continue with online shopping. The satisfaction includes receiving the right product ordered in timely manner. Good online shopping experiences depend heavily on good product information, easy payment method, fast delivery and low risk involved in terms of privacy and security, quality visual appeal, entertainment and enjoyment. Therefore, the perceived past experience affects the young shoppers' preference to shop online when they are confidence from their previous online shopping experience that the outcomes were satisfactory. Based on the objectives of this study, it is concluded that, online shopping is more appealing from offline stores for female young shoppers age 15 to 30 years old in Kelantan do online shopping once among and majority of them with income below RM5,000. They prefer online shopping because the online retailers provide more competitive prices and varieties of products with exciting shopping offers that make them feel good and at ease doing online shopping. Among the preferences made, perceived ease of use is the most dominant factor that shape their online shopping preference.

While this research has clearly identified the factors that influence young shoppers online shopping preference, however, this study performed with minimal sources that limits the scope of analysis and sample size that may affect the quality of the results. Despite the marked increase in online shopping, there is evidence that the wave in Kelantan is not the same. Lack of trust to sellers and security issues in online transaction are still a matter of concern to young shoppers when choosing online as their shopping channel. Nowadays, many sellers take advantage on breaching the consumers' data privacy to engage with online fraud. Thus, it is important that young consumers are protected with responsible bodies like National Consumer Complain Centre (NCCC), Malaysian Communication and Multimedia Commission (MCMC) and Polis Diraja Malaysia (PDRM) to eradicate the online fraud. With this security awareness, young shoppers are secured to do online shopping 
INTERNATIONAL JOURNAL OF ACADEMIC RESEARCH IN BUSINESS AND SOCIAL SCIENCES

Vol. 11, No. 14, Special Issue: Contemporary Business and Humanities Landscape Towards Sustainability, 2021, E-ISSN: 2222-6990 @ 2020 HRMARS

without having to worry on the misuse of their private data. There are several recommendations identified for future researchers. First, as this study use questionnaire to get a data, it was difficult to get the right information, availability of respondent and reliable resources in the internet. Second, similar studies should in future increase the sample size to a wider population for more reliable results to generalize the entire young consumer online shopping preference in Malaysia. Third, as ecommerce rise in popularity globally, future research should investigate the factors that affect young shoppers' online shopping preference across multinational settings.

\section{References}

Akroush, M. N., \& Al-Debei, M. M. (2015). An integrated model of factors affecting consumer attitudes towards online shopping. Business Process Management Journal, 21(6), 1353-1376. doi:10.1108/bpmj-02-2015-0022

Al-Debei, M. M., Akroush, M. N., \& Ashouri, M. I. (2015). Consumer attitudes towards online shopping. Internet Research, 25(5), 707-733. doi:10.1108/intr-05-2014-0146

Arora, N., \& Aggarwal, A. (2018). The role of perceived benefits in formation of online shopping attitude among women shoppers in India. South Asian Journal of Business Studies, 7(1), 91110. doi:10.1108/sajbs-04-2017-0048

Bhatnagar, A., \& Ghose, S. (2004). Segmenting consumers based on the benefits and risks of internet shopping. Journal of Business Research, 57(12), 1352-1360. doi:10.1016/s01482963(03)00067-5

Blake, B. F., Neuendorf, K. A., \& Valdiserri, C. M. (2003). Innovativeness and variety of internet shopping. Internet Research, 13(3), 156-169. doi:10.1108/10662240310478187

Carter, L., \& Schaupp, L. C. (n.d.). Relating acceptance and optimism to E-file adoption. Applied Technology Integration in Governmental Organizations, 244-256. doi:10.4018/978-1-60960162-1.ch015

Chen, C. D., \& Cheng, C. J. (2009). Understanding consumer intention in online shopping: A respecification and validation of the DeLone and McLean model. Behaviour \& Information Technology, 28(4), 335-345. doi:10.1080/01449290701850111

Chu, R., Wang, H., Wang, Y., \& Zhang, C. (2017). Research on intelligent decision making technology of fire emergency rescue. 2017 29th Chinese Control And Decision Conference (CCDC). doi:10.1109/ccdc.2017.7978816

Gabor, A. (1979). Price and consumer behaviour-A review. Management Decision, 17(8), 724-741. doi:10.1108/eb001223

Goldsmith, R. E. (2001). Using the domain specific Innovativeness scale to identify innovative internet consumers. Internet Research, 11(2), 149-158. doi:10.1108/10662240110695098

Han, B., Kim, M., \& Lee, J. (2018). Exploring consumer attitudes and purchasing intentions of crossborder online shopping in Korea. Journal of Korea Trade, 22(2), 86-104. doi:10.1108/jkt-102017-0093

Izogo, E. E., \& Jayawardhena, C. (2018). Online shopping experience in an emerging E-rEtailing market: Towards a conceptual model. Journal of Consumer Behaviour, 17(4), 379-392. doi:10.1002/cb.1715

Janson, M., \& Cecez-Kecmanovic, D. (2005). Making sense of E-commErcE as social action. Information Technology \& People, 18(4), 311-342. doi:10.1108/09593840510633301 
INTERNATIONAL JOURNAL OF ACADEMIC RESEARCH IN BUSINESS AND SOCIAL SCIENCES

Vol. 11, No. 14, Special Issue: Contemporary Business and Humanities Landscape Towards Sustainability, 2021, E-ISSN: 2222-6990 @ 2020 HRMARS

Jibril, A. B., Kwarteng, M. A., Pilik, M., Botha, E., \& Osakwe, C. N. (2020). Towards understanding the initial adoption of online retail stores in a low internet penetration context: An exploratory work in Ghana. Sustainability, 12(3), 854. doi:10.3390/su12030854

Kacen, J. J., Hess, J. D., \& Chiang, K. W. (2013). Bricks or clicks? Consumer attitudes toward traditional stores and online stores. Global Economics and Management Review, 18(1), 12-21. doi:10.1016/s2340-1540(13)70003-3

Ariffin, K. S., Mohan, T., \& Goh, Y. (2018). Influence of consumers' perceived risk on consumers' online purchase intention. Journal of Research in Interactive Marketing, 12(3), 309-327. doi:10.1108/jrim-11-2017-0100

Kim, S., \& Park, H. (2013). Effects of various characteristics of social commerce (S-commerce) on consumers' trust and trust performance. International Journal of Information Management, 33(2), 318-332. doi:10.1016/j.ijinfomgt.2012.11.006

Labuschagne, L., \& Eloff, J. (2000). Electronic commerce: The information-security challenge. Information Management \& Computer Security, 8(3), 154-157. doi:10.1108/09685220010372582

Limayem, M., Khalifa, M., \& Frini, A. (2000). What makes consumers buy from internet? A longitudinal study of online shopping. IEEE Transactions on Systems, Man, and Cybernetics Part A: Systems and Humans, 30(4), 421-432. doi:10.1109/3468.852436

Mishra, O., \& Ayatham, P. (2017). Online retailers connecting to the youth segment through Facebook (A study on the influence of gender and personality type). Journal of Asia Business Studies, 11(4), 387-412. doi:10.1108/jabs-08-2015-0129

Multivariate statistics. (2007). Tabachnick, B. G., \& Fidell, L.S (2007). Using Multivariate Statistics, Fifth Edition. doi:10.1007/978-0-387-73508-5

Murphy, P. E., \& Enis, B. M. (1986). Classifying products strategically. Journal of Marketing, 50(3), 2442. doi:10.1177/002224298605000303

Narges, D., \& Laily, H. P. (2011). Determinants of financial wellness among Malaysia workers. African Journal of Business Management, 5(24), 10092-10100. doi:10.5897/ajbm10.1267

Parker, C. J., \& Wang, H. (2016). Examining hedonic and utilitarian motivations for M-coMMerce fashion retail app engagement. Journal of Fashion Marketing and Management: An International Journal, 20(4), 487-506. doi:10.1108/jfmm-02-2016-0015

Rajamma, R. K., Paswan, A. K., \& Hossain, M. M. (2009). Why do shoppers abandon shopping cart? Perceived waiting time, risk, and transaction inconvenience. Journal of Product \& Brand Management, 18(3), 188-197. doi:10.1108/10610420910957816

Robinson, C. (2017). Disclosure of personal data in ecommerce: A cross-national comparison of Estonia and the United States. Telematics and Informatics, 34(2), 569-582. doi:10.1016/j.tele.2016.09.006

Seo, S., \& Moon, S. (2016). Decision-making styles of restaurant deal consumers who use social commerce. International Journal of Contemporary Hospitality Management, 28(11), 24932513. doi:10.1108/ijchm-06-2015-0319

Sheikh, Z., Yezheng, L., Islam, T., Hameed, Z., \& Khan, I. U. (2019). Impact of social commerce constructs and social support on social commerce intentions. Information Technology \& People, 32(1), 68-93. doi:10.1108/itp-04-2018-0195

Shergill, G. S., \& Chen, Z. (2004). Shopping on the internet-online purchase behavior of New Zealand consumers. Journal of Internet Commerce, 3(4), 61-77. doi:10.1300/j179v03n04_04 
INTERNATIONAL JOURNAL OF ACADEMIC RESEARCH IN BUSINESS AND SOCIAL SCIENCES

Vol. 11, No. 14, Special Issue: Contemporary Business and Humanities Landscape Towards Sustainability, 2021, E-ISSN: 2222-6990 @ 2020 HRMARS

SungEuiCho. (2011). Factors affecting customer purchase intention in electronic commerce of service products. Journal of Korea Service Management Society, 12(5), 83-107. doi:10.15706/jksms.2011.12.5.004

Tandon, U., Kiran, R., \& Sah, A. N. (2017). The influence of website functionality, drivers and perceived risk on customer satisfaction in online shopping: An emerging economy case. Information Systems and e-Business Management, 16(1), 57-91. doi:10.1007/s10257-0170341-3

Citrin, V. A., Sprott, D. E., Silverman, S. N., \& Stem, D. E. (2000). Adoption of internet shopping: The role of consumer innovativeness. Industrial Management \& Data Systems, 100(7), 294-300. doi:10.1108/02635570010304806

Zhang, P., Wang, Y., Wang, J., Zeng, X., \& Wang, Y. (2017). An improved term weighting scheme for sentiment classification. 2017 IEEE 2nd Advanced Information Technology, Electronic and Automation Control Conference (IAEAC). doi:10.1109/iaeac.2017.8054057 